\title{
TRIzol treatment of secretory phase endometrium allows combined proteomic and mRNA microarray analysis of the same sample in women with and without endometriosis
}

Amelie Fassbender ${ }^{1}$, Peter Simsa ${ }^{1}$, Cleophas M Kyama ${ }^{1,2}$, Etienne Waelkens ${ }^{3}$, Attila Mihalyi ${ }^{1}$, Christel Meuleman ${ }^{1}$, Olivier Gevaert ${ }^{4}$, Raf Van de Plas ${ }^{4}$, Bart de Moor ${ }^{4}$, Thomas M D'Hooghe ${ }^{1,2^{*}}$

\begin{abstract}
Background: According to mRNA microarray, proteomics and other studies, biological abnormalities of eutopic endometrium (EM) are involved in the pathogenesis of endometriosis, but the relationship between mRNA and protein expression in EM is not clear. We tested for the first time the hypothesis that EM TRIzol extraction allows proteomic Surface Enhanced Laser Desorption/Ionisation Time-of-Flight Mass Spectrometry (SELDI-TOF MS) analysis and that these proteomic data can be related to mRNA (microarray) data obtained from the same EM sample from women with and without endometriosis.
\end{abstract}

Methods: Proteomic analysis was performed using SELDI-TOF-MS of TRIzol-extracted EM obtained during secretory phase from patients without endometriosis $(n=6)$, patients with minimal-mild $(n=5)$ and with moderate-severe endometriosis $(n=5)$, classified according to the system of the American Society of Reproductive Medicine. Proteomic data were compared to mRNA microarray data obtained from the same EM samples.

Results: In our SELDI-TOF MS study 32 peaks were differentially expressed in endometrium of all women with endometriosis (stages I-IV) compared with all controls during the secretory phase. Comparison of proteomic results with those from microarray revealed no corresponding genes/proteins.

Conclusion: TRIzol treatment of secretory phase EM allows combined proteomic and mRNA microarray analysis of the same sample, but comparison between proteomic and microarray data was not evident, probably due to posttranslational modifications.

\section{Background}

Endometriosis is a gynaecological disorder, defined as the presence of endometrial-like tissue outside the uterus and is associated with chronic intrapelvic inflammation. Its symptoms can impact on general well-being [1] and include severe dysmenorrhoea; deep dyspareunia; chronic pelvic pain; cyclical or premenstrual symptoms (e.g. bowel or bladder associated) with or without abnormal bleeding; infertility and chronic fatigue.

\footnotetext{
* Correspondence: thomas.dhooghe@uzleuven.be 'Leuven University Fertility Centre, Department of Obstetrics \& Gynaecology, University Hospital Gasthuisberg, Leuven, Belgium
} Full list of author information is available at the end of the article
Well established biological differences between eutopic endometrium from women with and without endometriosis represent an interesting scientific basis to develop a semi-invasive diagnostic test for endometriosis based on these differences. Recent evidence suggests that significant biological differences between eutopic endometrium from women with and without endometriosis [2] may offer the basis for a semi-invasive diagnostic test based on the analysis of an endometrial biopsy. Numerous proteomic [3-10] and mRNA microarray [11-14] studies have demonstrated important biological differences between eutopic endometrium from women with and without endometriosis. Furthermore, data from other investigators [15-17] and from our group [18] 
suggest that endometriosis can be diagnosed based on the increased endometrial density of nerve fibres in women with endometriosis compared to controls.

The primary aim of this study was to test the hypothesis that TRIzol extraction of endometrium enables a combined mRNA microarray and proteomic analysis of the same EM sample from both women with and without endometriosis. The secondary aim of our study was to compare proteomic data (presented in this study) with mRNA microarray data [13] of the same EM sample.

\section{Methods}

\section{Patient selection}

The same endometrium samples selected for this study were as those used in our previous microarray study [13]. Briefly, the biobank of the Leuven University Fertility Centre was searched to identify 16 endometrial (EM) samples obtained during the secretory phase (dated between day 23 - 26) from each of the following 3 groups, women with a normal pelvis (controls, $\mathrm{n}=6$ ), women with minimal to mild endometriosis (stages I-II, $\mathrm{n}=5$ ), and from women with moderate to severe endometriosis (stages III-IV, $\mathrm{n}=5$ ). Endometriosis was staged according to the classification system of the American Society of Reproductive Medicine [19]. Endometrial samples had been collected during hysteroscopy/laparoscopy procedures for either infertility or pain and had been frozen at $-80^{\circ} \mathrm{C}$ until use. None of our patients took oral contraceptives or other hormonal treatment for endometriosis within 3 months prior to EM sample collection. Women with and without endometriosis had the following age (mean 28.10 $\pm 2,767$, median 27.5, range 26-29.5 years) and (mean 32.33 \pm 3.933 , median 33, range 28.50-35.5 years), respectively. All patients had signed a written informed consent before surgery and had agreed on the collection of tissues for research. The study protocol had been approved by the institutional ethical and review board of the University Hospital Gasthuisberg for the protection of human subjects.

\section{Preparation of endometrial samples}

TRIzol (Invitrogen Life Technologies, Carlsbad CA, USA) [20], a monophasic solution of phenol and guanidine isothiocyanate, was used as a one step reagent for the extraction of RNA, Protein from each EM sample. The protein quantity and quality was analyzed on the Nanodrop and protein measurements ranged between 0,39 to $16 \mathrm{mg} / \mathrm{ml}$. $10 \mu \mathrm{g}$ of protein concentration were used to spot on each surface.

Frozen EM tissue biopsies were immediately thawed in TRIzol reagent according to the instructions of the manufacturers. Briefly, tissues were homogenized using a glass tube with a glass stick to smash the sample to pieces, $300 \mu \mathrm{l} / 105 \mu \mathrm{l}$ chloroform were added and left at room temperature for five minutes. The samples were centrifuged at $10000 \mathrm{rpm}$ at $4^{\circ} \mathrm{C}$ for 15 minutes. The upper aqueous phase was separated and washed with Qiagen kit (following manufacturer's instructions). The aliquot including the protein fraction were thawed on ice and sonicated. $600 \mu \mathrm{l}$ acetone was added with inversion and left at room temperature for $10 \mathrm{~min}$. The samples were centrifuged at $12000 \mathrm{rpm}$ at $4{ }^{\circ} \mathrm{C}$ for 10 minutes. Twice $0.5 \mathrm{ml}$ of $0.3 \mathrm{M}$ urea in $95 \%$ ethanol was added and left at room temperature for $10 \mathrm{~min}$. The samples were centrifuged at $8,000 \mathrm{~g}$ for 5 minutes and twice $1 \mathrm{ml}$ of urea/ethanol were added and dissolved in $300 \mu$ l U9 Ciphergen (9 M Urea, 2\% 3-[(3-cholamidopropyl) dimethyl-ammonio]-1-propanesulfonate (CHAPS), $50 \mathrm{mM}$ tris(hydroxymethyl)aminomethane$\mathrm{HCl}$ (Tris- $\mathrm{HCl}$ ) pH 9.0) (Ciphergen Biosystems, Fremont, CA, USA). The samples were sonicated and left at room temperature for 10-20 minutes and spun at $8,000 \mathrm{~g}$ for 5 minutes to sediment the insoluble protein. The samples were stored at $-80^{\circ} \mathrm{C}$.

\section{ProteinChip Arrays}

First a brief test phase was performed on four chip types (Cm10, IMAC30-Cu, H50 and Q10) to find the best (rich spectra) chip type for this experiment. Two different chip surfaces with distinct chromatographic properties and binding affinities were used, Weak cation exchange surface (CM10) with a low stringency binding buffer $(50 \mathrm{mM} \mathrm{NaOAC}, \mathrm{pH} 4.0)$ and Immobilized metallic affinity capture surface (IMAC-30-Cu) loaded with $\mathrm{CuSO}_{4}$, with a $0.1 \mathrm{M}$ phosphate, $0.5 \mathrm{M} \mathrm{NaCl}$, pH7.0.

Briefly, ProteinChip array spots were equilibrated with $150 \mu \mathrm{l}$ of respective binding buffer (Ciphergen, Fremont, CA, USA) while shaking twice for five minutes at room temperature to pre-activate binding surfaces. Then, $20 \mu \mathrm{l}$ of sample $(10 \mu \mathrm{g}$ per spot) diluted $(1: 5 \mathrm{vol} / \mathrm{vol})$ with the surface-type dependent binding buffer were loaded onto each spot in duplicate and incubated for 60 minutes at room temperature while being shaken in the dark (MicroMix5, form 20, amplitude 5; Diagnostics Product Corporation, Gwynedd, Wales, United Kingdom). The unbound proteins/peptides on the ProteinChip array surfaces were washed away with appropriate buffer twice for 5 minutes rinsed in $150 \mu \mathrm{l}$ of Milli-Q water and air-dried. Mass spectra of the retained proteins were obtained by ionising the proteins using two types of energy absorbing molecules (EAM): alpha-cyano-4-hydroxy cinnamic acid (CHCA), for small molecules $(<15 \mathrm{kDa})$, and sinapinic acid (SPA), for larger molecules (both EAM were obtained from Ciphergen, Fremont, CA, USA). The CHCA ( $5 \mathrm{mg}$ CHCA dissolved in $150 \mu \mathrm{l}$ of $50 \%$ 
acetonitrile, $0.5 \%$ trifluoroacetic acid) was diluted five times in the respective solvent, and $1 \mu \mathrm{l}$ was applied twice onto the retained proteins on the spots. The SPA $(5 \mathrm{mg}$ SPA dissolved in $400 \mu \mathrm{l}$ of $50 \%$ acetonitrile, $0.5 \%$ trifluoroacetic acid) was applied in two consecutive steps in volumes of $1 \mu \mathrm{l}$. Analysis of the retained proteins was performed with a Protein Biological System-IIC (PBSIIC) linear SELDI-TOF-MS instrument (Ciphergen). Mass accuracy was calibrated externally with the all-in-one peptide molecular mass standard (Ciphergen Biosystems, Fremont, CA, USA) for the mass range of $1.6 \mathrm{kDa}-20 \mathrm{kDa}$ and with the all-in-one protein molecular mass standard (Ciphergen Biosystems, Fremont, CA, USA) for the mass range of 8-150 kDa.

\section{Statistical analysis of proteomic data}

The SELDI-TOF mass spectra were baseline corrected and normalised on the basis of total ion current using the Biomarker Wizard Program (Ciphergen, Fremont, CA, USA). The same application was used for peak detection and the determination of $p$-values. All univariate analyses were carried out using Ciphergen's ProteinChip Software v3.1.1 (Ciphergen, Fremont, CA, USA) and the Prism 5 software (GraphPad, San Diego, CA, USA). Results are expressed as mean.

\section{Comparison of proteomics and microarray data}

The endometrium samples of the mRNA microarray study which were used in this study revealed that 9 genes were differentially expressed in women with and without endometriosis. The molecular weights of these 9 representative proteins [13] were identified using a search via [21] and are shown in Table 1.

\section{Results/Discussion}

In this study, we showed for the first time that combined analysis of one endometrial sample from women with and without endometriosis for both mRNA (Microarray) and protein fraction (SELDI-TOF MS) is possible after TRIzol extraction. Although we were able to compare these endometrial samples with respect to mRNA protein expression (microarray, [13]) and protein expression (proteomics, presented in this study), no corresponding proteins/genes were found.

In our mRNA microarray study [13] 8 genes were upregulated and one gene was down-regulated in eutopic endometrium of women with endometriosis compared to controls. Real-time PCR analysis of protocadherin-17 (PCDH17), protein tyrosine phosphatase, receptor type, $R$ (PTPRR) and interleukin-6 signal transducer (IL6ST) expression validated the microarray findings [Table 1; [13]]. In our SELDI-TOF MS study 32 peaks were differentially expressed in endometrium of all women with
Table 1 The representative molecular weights of the proteins identified in the mRNA Microarray study [13]

\begin{tabular}{|c|c|}
\hline Protein & Mass in Da \\
\hline Osteoglycin (OGN/4969) & 33,922 \\
\hline Interleukin-6 signal transducer (IL6ST/3572) & $\begin{array}{l}\text { isoform 1. 103,537 } \\
\text { isoform 2. 37,499 }\end{array}$ \\
\hline $\begin{array}{l}\text { Cytochrome P450, Family 2, Subfamily J, } \\
\text { polypeptide } 2 \text { (CYP2J2/1573) }\end{array}$ & 57,611 \\
\hline Carboxypeptidase E (CPE/1363) & 53,151 \\
\hline Fibronectin 1 (FN1/2335) & $\begin{array}{c}\text { different isoforms } \\
\text { 1. } 262,607 \\
\text { 2. } 71,943 \\
\text { 3. } 259,198 \\
\text { 4. } 222,944 \\
\text { 5. } 243,316 \\
\text { 6. } 240,477 \\
\text { 7. } 268,894 \\
\text { 8. } 252,793 \\
\text { 9. } 246,670 \\
\text { 10. } 239,608 \\
\text { 11. } 262,388 \\
\text { 12. } 221,274 \\
\text { 13. } 249,304 \\
\text { 14. } 249,384 \\
\text { 15. } 272,302\end{array}$ \\
\hline Synuclein, gamma (SNCG/6623) & 13,331 \\
\hline BAI1-associated protein 2 (BAIAP2/10458) & $\begin{array}{c}\text { different isoforms } \\
\text { 1. } 60,868 \\
\text { 2. } 59,014 \\
\text { 3. } 56,626 \\
\text { 4. } 57,359 \\
\text { 5. } 57,445 \\
\text { 6. } 57,430\end{array}$ \\
\hline Protocadherin $17(\mathrm{PCDH} 17 / 27253)$ & $\begin{array}{c}\text { different isoforms } \\
\text { 1. } 126,229 \\
\text { 2. } 96,570\end{array}$ \\
\hline
\end{tabular}

endometriosis (stages I-IV) compared with all controls during the secretory phase [Table 2]. The proteins of interest detected by SELDI-TOF MS had a lower range (5-32 kDa) than the 9 genes detected by mRNA (representative protein range 33-272 $\mathrm{kDa},[13]$ ) with the exception of Synuclein, gamma which has a range of molecular weight of $13 \mathrm{kDa}$. This observation can be explained by the fact that protein activity often depends on post-translational modifications, which are not predictable from the level of the corresponding transcript [22], and confirm recent data [7] that eutopic endometrial protein expression, analyzed by 2D-differential in gel electrophoresis (DIGE) and mass spectrometry, does not correlate well with published gene array data.

Although it is not clear why different mass peaks were observed in results comparing moderate-severe endometriosis (25 peaks) versus controls as opposed to results comparing minimal-mild endometriosis (23 peaks) versus controls [Table 3 and 4], it is possible that specific peptides or proteins are associated with specific stages of the disease. It is also not clear why the proteomic 
Table 2 Mean signal intensities of various proteins and peptides comparing endometrium of women with a normal pelvis versus endometriosis (CM10 and IMAC)

\begin{tabular}{|c|c|c|c|c|}
\hline \multicolumn{5}{|l|}{ CM10 } \\
\hline \multicolumn{5}{|l|}{$\mathrm{CHCA}$} \\
\hline$M / Z$ & pvalue & Mean Disease & Mean Control & Up/down \\
\hline 14653,82 & 0,034 & 0,795 & 1,468 & down \\
\hline 16851,18 & 0,020 & 0,378 & 0,660 & down \\
\hline \multicolumn{5}{|l|}{ SPAhigh } \\
\hline 8776,32 & 0,020 & 0,854 & 0,310 & up \\
\hline 8898,40 & 0,045 & 4,530 & 1,935 & up \\
\hline 10115,90 & 0,034 & 7,442 & 3,545 & up \\
\hline 12186,64 & 0,026 & 0,300 & 0,132 & up \\
\hline 12379,95 & 0,011 & 2,028 & 0,420 & up \\
\hline 12683,46 & 0,026 & 0,988 & 0,444 & up \\
\hline 13464,70 & 0,045 & 0,361 & 0,198 & up \\
\hline 14479,03 & 0,011 & 0,282 & 0,116 & up \\
\hline 17258,59 & 0,034 & 0,370 & 0,168 & up \\
\hline \multicolumn{5}{|l|}{ SPAlow } \\
\hline 7662,79 & 0,045 & 0,247 & 0,362 & down \\
\hline 8949,82 & 0,026 & 1,310 & 0,720 & up \\
\hline 9177,29 & 0,020 & 0,391 & 1,381 & down \\
\hline 9941,98 & 0,026 & 2,221 & 1,234 & up \\
\hline 10084,76 & 0,045 & 1,807 & 1,096 & up \\
\hline 11477,23 & 0,034 & 0,087 & 0,167 & down \\
\hline 12323,14 & 0,011 & 0,652 & 0,215 & up \\
\hline 12623,72 & 0,045 & 0,375 & 0,219 & up \\
\hline \multicolumn{5}{|c|}{ IMAC } \\
\hline \multicolumn{5}{|l|}{ CHCA } \\
\hline$M / z$ & pvalue & Mean Disease & Mean Control & Up/down \\
\hline 6299,93 & 0,011 & 0,319 & 0,470 & down \\
\hline 9213,51 & 0,008 & 0,607 & 1,578 & down \\
\hline 9266,22 & 0,011 & 0,933 & 1,440 & down \\
\hline 9766,19 & 0,034 & 0,699 & 0,360 & up \\
\hline 11163,87 & 0,020 & 0,527 & 0,245 & up \\
\hline 11322,71 & 0,015 & 1,017 & 0,294 & up \\
\hline 15446,04 & 0,004 & 0,586 & 0,108 & up \\
\hline \multicolumn{5}{|l|}{ SPAhigh } \\
\hline 9532,42 & 0,026 & 3,217 & 13,993 & down \\
\hline 9767,55 & 0,045 & 2,180 & 4,258 & down \\
\hline \multicolumn{5}{|l|}{ SPAlow } \\
\hline 7832,06 & 0,020 & 0,205 & 0,369 & down \\
\hline 8228,62 & 0,004 & 0,389 & 0,198 & up \\
\hline 9190,05 & 0,015 & 0,420 & 1,406 & down \\
\hline 9262,94 & 0,034 & 0,900 & 0,502 & up \\
\hline
\end{tabular}

peaks identified in EM samples in our previous studies $[5,6]$ were not confirmed in the present study. In our first pilot study, [6] SELDI-TOF MS profiling of EM samples showed that the expression of proteins and peptides in the range of $2.8-12.3 \mathrm{kDa}$ was $3-24$ times lower in endometrium of women with endometriosis compared with in women without endometriosis. In our
Table 3 Mean signal intensities of various proteins and peptides comparing endometrium of women with a normal pelvis versus stage I-II endometriosis (CM10 and IMAC)

\begin{tabular}{|c|c|c|c|c|}
\hline \multicolumn{5}{|l|}{ CM10 } \\
\hline \multicolumn{5}{|l|}{ SPAhigh } \\
\hline$M / z$ & pvalue & Mean Disease & Mean Control & Up/down \\
\hline 8898,40 & 0,036 & 4,475 & 1,935 & up \\
\hline 10115,90 & 0,036 & 8,002 & 3,545 & up \\
\hline 11656,79 & 0,036 & 6,899 & 2,721 & up \\
\hline 11861,80 & 0,008 & 3,013 & 1,160 & up \\
\hline 12186,64 & 0,014 & 0,386 & 0,132 & up \\
\hline 12379,95 & 0,008 & 1,580 & 0,420 & up \\
\hline 12847,34 & 0,023 & 0,668 & 0,228 & up \\
\hline 13464,70 & 0,036 & 0,432 & 0,198 & up \\
\hline 14659,37 & 0,023 & 2,197 & 1,049 & up \\
\hline \multicolumn{5}{|l|}{ SPAlow } \\
\hline 7662,79 & 0,036 & 0,190 & 0,362 & down \\
\hline 8078,54 & 0,022 & 0,118 & 0,339 & down \\
\hline 8949,82 & 0,008 & 1,326 & 0,720 & up \\
\hline 9941,98 & 0,008 & 2,382 & 1,234 & up \\
\hline 10084,76 & 0,022 & 1,900 & 1,096 & up \\
\hline 11801,42 & 0,014 & 0,875 & 0,432 & up \\
\hline 11835,69 & 0,008 & 0,507 & 0,284 & up \\
\hline 12323,14 & 0,008 & 0,727 & 0,215 & up \\
\hline 15199,86 & 0,014 & 0,010 & 0,088 & down \\
\hline \multicolumn{5}{|l|}{ IMAC } \\
\hline \multicolumn{5}{|l|}{ CHCA } \\
\hline$M / z$ & pvalue & Mean Disease & Mean Control & Up/down \\
\hline 11163,87 & 0,022 & 0,469 & 0,245 & up \\
\hline 11322,71 & 0,008 & 0,836 & 0,294 & up \\
\hline 13815,44 & 0,014 & 3,281 & 1,411 & up \\
\hline 15446,04 & 0,036 & 0,283 & 0,108 & up \\
\hline \multicolumn{5}{|l|}{ SPAlow } \\
\hline 8228,62 & 0,014 & 0,429 & 0,198 & up \\
\hline
\end{tabular}

second study [5], the combination of SELDI-TOF MS ProteinChip technology with bioinformatics allowed us to develop a diagnostic test for minimal-mild endometriosis based on a panel of 4 mass peaks ( 2 up-regulated: $90.675 \mathrm{kDa}$ and $35.956 \mathrm{kDa}$ and 2 down-regulated: 1.9 $\mathrm{kDa}$ and $2.5 \mathrm{kDa}$ ) with maximal sensitivity $(100 \%)$ and specificity (100\%). We hypothesize that various factors may contribute to this lack of confirmation. Firstly, the protein extraction method was based on TRIzol (Invitrogen Life Technologies, Carlsbad CA, USA) in the current study and on U9 lysis buffer (Ciphergen Biosystems, Fremont, CA) in our previous studies [5,6]. Secondly, endometrial biological changes related to the menstrual cycle [23] may lead to differential protein expression in EM samples obtained on day 23-26 of the cycle (current study), compared to EM samples obtained during secretory phase (day 20-22) or 
Table 4 Mean signal intensities of various proteins and peptides comparing endometrium of women with a normal pelvis versus stage III-IV endometriosis (CM10 and IMAC)

\begin{tabular}{|c|c|c|c|c|}
\hline CM10 & & & & \\
\hline \multicolumn{5}{|l|}{$\mathrm{CHCA}$} \\
\hline$M / z$ & pvalue & Mean Disease & Mean Control & Up/down \\
\hline 9774,53 & 0,014 & 0,596 & 1,098 & down \\
\hline 14653,82 & 0,008 & 0,445 & 1,468 & down \\
\hline \multicolumn{5}{|l|}{ SPAhigh } \\
\hline 14479,03 & 0,014 & 0,266 & 0,116 & up \\
\hline 31793,90 & 0,036 & 1,596 & 0,142 & up \\
\hline \multicolumn{5}{|l|}{ SPAlow } \\
\hline 8172,88 & 0,014 & 0,237 & 0,417 & down \\
\hline 8388,16 & 0,036 & 0,126 & 0,362 & down \\
\hline 9177,29 & 0,022 & 0,145 & 1,381 & down \\
\hline 9399,55 & 0,036 & 0,180 & 0,415 & down \\
\hline 9616,30 & 0,008 & 0,100 & 0,307 & down \\
\hline 11477,23 & 0,014 & 0,058 & 0,167 & down \\
\hline 12623,72 & 0,036 & 0,340 & 0,219 & up \\
\hline 12787,28 & 0,036 & 0,036 & 0,132 & down \\
\hline 15765,886 & 0,036 & 2,103 & 0,186 & up \\
\hline \multicolumn{5}{|l|}{ IMAC } \\
\hline \multicolumn{5}{|l|}{ CHCA } \\
\hline$M / z$ & pvalue & Mean Disease & Mean Control & Up/down \\
\hline 6299,9273 & 0,008113117 & 0,23461589 & 0,47046801 & down \\
\hline 9213,5098 & 0,01371083 & 0,362215739 & 1,57790751 & down \\
\hline 9266,2242 & 0,022478873 & 0,695244394 & 1,44011883 & down \\
\hline 9766,1943 & 0,035763767 & 0,764862056 & 0,35977499 & up \\
\hline 15446,04 & 0,008 & 0,985 & 0,108 & up \\
\hline \multicolumn{5}{|l|}{ SPAhigh } \\
\hline 9532,42 & 0,023 & 1,056 & 13,993 & down \\
\hline 9767,55 & 0,036 & 1,436 & 4,258 & down \\
\hline 13134,421 & 0,0137 & 0,23780214 & 0,53548423 & down \\
\hline \multicolumn{5}{|l|}{ SPAlow } \\
\hline 7716,86 & 0,036 & 0,587 & 0,253 & up \\
\hline 7832,06 & 0,036 & 0,204 & 0,369 & down \\
\hline 8228,62 & 0,022 & 0,291 & 0,198 & up \\
\hline 9190,0544 & 0,00811312 & 0,21041195 & 1,4064187 & down \\
\hline
\end{tabular}

secretory phase (day 16 - 26) in our previous studies $[5,6]$. Indeed, EM histology on cycle days 23-26 is marked by decreasing secretion, decreasing stromal edema, increasing pseudodecidual reaction, stromal mitoses, and leucocytic infiltration, whereas endometrial secretion on cycle days $18-22$ is maximal with a low proportion of stromal mitoses, and absence of pseudodecidual reaction or leucocytic infiltration [23]. Furthermore, endometrial mRNA expression has also been reported to be affected differently during different phases of the cycle [24]. Thirdly, it has to be acknowledged that proteomic techniques like SELDI-TOF MS still require standardization on the level of intra- and interassay variability. Therefore, we plan to repeat this study in a larger sample size including well defined endometrial samples obtained during menstrual, follicular and secretory phase, to validate the reproducibility of SELDI-TOF MS technology in these samples and to identify the protein peaks observed after proteomic analysis, which are expensive and labour intense requiring High-performance liquid chromatography or high-pressure liquid chromatography (HPLC) and matrix assisted laser desorption ionization Time-ofFlight-Mass Spectrometry (MALDI-TOF MS).

\section{Conclusion}

TRIzol treatment of secretory phase EM allowed both proteomic (SELDI-TOF MS) and mRNA microarray analysis of the same sample, but comparison of protein and mRNA expression in the same sample was not evident, probably due to post-translational modifications and/or technical aspects.

\begin{abstract}
Abbreviations
EAM: energy absorbing molecules; EM: endometrium; 2D-differential in gel electrophoresis (DIGE); HPLC: High-performance liquid chromatography or high-pressure liquid chromatography; IMAC: immobilised metal affinity capture; MALDI-TOF/TOF-MS: matrix assisted laser desorption ionization Time-of-Flight-Mass Spectrometry ; PBS IIC: Protein Biological System-IIC; CHCA: alpha-cyano-4-hydroxy cinnamic acid; SPA: sinapinic acid; SELDI-TOFMS: Surface Enhanced Laser Desorption/Ionisation Time-of-Flight-Mass Spectrometry.
\end{abstract}

\section{Acknowledgements}

This work was supported by grants from the Leuven University Council (Dienst Onderzoekscoordinatie, K.U.Leuven, Leuven, Belgium), the Flemish Fund for Scientific Research (FWO), Leuven - Belgium and K.U.Leuven Interfaculty Council for development Cooperation, Leuven, Belgium.

\section{Author details \\ 'Leuven University Fertility Centre, Department of Obstetrics \& Gynaecology, University Hospital Gasthuisberg, Leuven, Belgium. ${ }^{2}$ Division of Reproductive Health and Biology, Institute of Primate Research, P.O. Box 24481-00502 Karen, Nairobi, Kenya. ${ }^{3}$ Biochemistry Section, Department of Molecular Cell Biology, Campus Gasthuisberg, Leuven, Belgium. ${ }^{4}$ Department of Electrical Engineering, ESAT-SCD, K.U.Leuven, Kasteelpark-Arenberg 10, B-3001 Heverlee, Belgium.}

\section{Authors' contributions}

AF, TD written manuscript, AF, TD, PS, CK, EW, AM, CM, drafting and revising the manuscript and data interpretation, AF, PS, CK, AM, CM, Sample collection, AF, TD, PS, CK, AM design of the experiment, AF, PS, CK experiment, AF, TD, OG, RV, BD, EW data analysis.

All authors read and approved the final manuscript.

\section{Competing interests}

The authors declare that they have no competing interests.

Received: 11 August 2010 Accepted: 21 October 2010 Published: 21 October 2010

\section{References}

1. Kennedy S, Bergqvist A, Chapron C, D'Hooghe T, Dunselman G, Greb R, Hummelshoj L, Prentice A, Saridogan E: ESHRE guideline for the diagnosis and treatment of endometriosis. Hum Reprod 2005, 20(10):2698-2704.

2. Giudice LC, Kao LC: Endometriosis. Lancet 2004, 364(9447):1789-1799. 
3. Ding $X$, Wang $L$, Ren $Y$, Zheng W: Detection of mitochondrial biomarkers in eutopic endometria of endometriosis using surface-enhanced laser desorption/ionization time-of-flight mass spectrometry. Fertil Steril 2010.

4. Fowler PA, Tattum J, Bhattacharya S, Klonisch T, Hombach-Klonisch S, Gazvani R, Lea RG, Miller I, Simpson WG, Cash P: An investigation of the effects of endometriosis on the proteome of human eutopic endometrium: a heterogeneous tissue with a complex disease. Proteomics 2007, 7(1):130-142.

5. Kyama CM, Mihalyi A, Gevaert O, Waelkens E, Simsa P, Van de Plas R, Meuleman C, De Moor B, D'Hooghe TM: Evaluation of endometrial biomarkers for semi-invasive diagnosis of endometriosis. Fertil Steril 2010.

6. Kyama CM, T'Jampens D, Mihalyi A, Simsa P, Debrock S, Waelkens E, Landuyt B, Meuleman C, Fulop V, Mwenda JM, et al: ProteinChip technology is a useful method in the pathogenesis and diagnosis of endometriosis: a preliminary study. Fertil Steril 2006, 86(1):203-209.

7. Stephens AN, Hannan NJ, Rainczuk A, Meehan KL, Chen J, Nicholls PK Rombauts LJ, Stanton PG, Robertson DM, Salamonsen LA: Post-translational modifications and protein-specific isoforms in endometriosis revealed by 2D DIGE. J Proteome Res 2010, 9(5):2438-2449.

8. Have S, Fraser I, Markham R, Lam A, Matsumoto I: Proteomic analysis of protein expression in the eutopic endometrium of women with endometriosis. Proteomics Clin Appl 2007, 1:1243-1251, ten.

9. Wang L, Zheng W, Ding XY, Yu JK, Jiang WZ, Zhang SZ: Identification biomarkers of eutopic endometrium in endometriosis using artificial neural networks and protein fingerprinting. Fertil Steril 2009, 93(7):2460-2462.

10. Zhang H, Niu Y, Feng J, Guo H, Ye X, Cui H: Use of proteomic analysis of endometriosis to identify different protein expression in patients with endometriosis versus normal controls. Fertil Steril 2006, 86(2):274-282

11. Burney RO, Talbi S, Hamilton AE, Vo KC, Nyegaard M, Nezhat CR, Lessey BA, Giudice LC: Gene expression analysis of endometrium reveals progesterone resistance and candidate susceptibility genes in women with endometriosis. Endocrinology 2007, 148(8):3814-3826.

12. Kao LC, Germeyer A, Tulac S, Lobo S, Yang JP, Taylor RN, Osteen K, Lessey BA, Giudice LC: Expression profiling of endometrium from women with endometriosis reveals candidate genes for disease-based implantation failure and infertility. Endocrinology 2003, 144(7):2870-2881.

13. Sherwin JR, Sharkey AM, Mihalyi A, Simsa P, Catalano RD, D'Hooghe TM: Global gene analysis of late secretory phase, eutopic endometrium does not provide the basis for a minimally invasive test of endometriosis. Hum Reprod 2008, 23(5):1063-1068.

14. Wu Y, Kajdacsy-Balla A, Strawn E, Basir Z, Halverson G, Jailwala P, Wang Y, Wang X, Ghosh S, Guo SW: Transcriptional characterizations of differences between eutopic and ectopic endometrium. Endocrinology 2006, 147(1):232-246

15. Tokushige N, Markham R, Russell P, Fraser IS: Different types of small nerve fibers in eutopic endometrium and myometrium in women with endometriosis. Fertil Steril 2007, 88(4):795-803.

16. Al-Jefout M, Dezarnaulds G, Cooper M, Tokushige N, Luscombe GM, Markham R, Fraser IS: Diagnosis of endometriosis by detection of nerve fibres in an endometrial biopsy: a double blind study. Hum Reprod 2009, 24(12):3019-3024.

17. Tokushige N, Markham R, Russell P, Fraser IS: High density of small nerve fibres in the functional layer of the endometrium in women with endometriosis. Hum Reprod 2006, 21(3):782-787.

18. Bokor AKC, Vercruysse L, Fassbender A, Gevaert O, Vodolazkaia A, De Moor B, Fülöp V, D'Hooghe T: Density of small diameter sensory nerve fibres in endometrium: a semi-invasive diagnostic test for minimal to mild endometriosis. Human Reproduction 2009, 24(12):3025-3032.

19. ASRM: Revised American Society for Reproductive Medicine classification of endometriosis: 1996. Fertil Steril 1997, 67(5):817-821.

20. Chomczynski P: A reagent for the single-step simultaneous isolation of RNA, DNA and proteins from cell and tissue samples. Biotechniques 1993, 15(3):532-534-536-537.

21. Expert Protein Analysis System:[http://www.expasy.ch].

22. Twyman RM: Principles of proteomics. Trowbridge: Cromwell press; 2007

23. Noyes RW, Hertig AT, Rock J: Dating the endometrial biopsy. Fertil Steril 1950, 1(1):3-25.

24. Talbi S, Hamilton AE, Vo KC, Tulac S, Overgaard MT, Dosiou C, Le Shay N, Nezhat CN, Kempson R, Lessey BA, et al: Molecular phenotyping of human endometrium distinguishes menstrual cycle phases and underlying biological processes in normo-ovulatory women. Endocrinology 2006, 147(3):1097-1121.

doi:10.1186/1477-7827-8-123

Cite this article as: Fassbender et al:: TRlzol treatment of secretory phase endometrium allows combined proteomic and mRNA microarray analysis of the same sample in women with and without endometriosis. Reproductive Biology and Endocrinology 2010 8:123.

\section{Submit your next manuscript to BioMed Central and take full advantage of:}

- Convenient online submission

- Thorough peer review

- No space constraints or color figure charges

- Immediate publication on acceptance

- Inclusion in PubMed, CAS, Scopus and Google Scholar

- Research which is freely available for redistribution 